AC 2001-1006: Teaching Temporary Structures: Style, Content and Outcome Gouranga Banik, 
Session 2306

\title{
TEACHING TEMPORARY STRUCTURES: STYLE, CONTENT AND OUTCOME
}

\author{
Gouranga C. Banik, Ph.D., P.E. \\ Construction Department \\ Southern Polytechnic State University \\ Marietta, GA 30060 \\ Tel: 770-528-3711, Fax: 770-528-4966 \\ E-mail: gbanik@spsu.edu
}

\begin{abstract}
Facilities are becoming more complex in respect to architecture and engineering along with the increasing competition in the construction and design market. This changing construction environment demands more advanced use of temporary structures for economy and safety. In this scenario, temporary construction structures coursework can play an essential role for the architectural/civil engineering and construction students during their careers. But teaching this class is not the same as teaching standard structure classes. The contents, objectives and format of this class are more likely different. Few ABET and ACCE accredited programs offer this course to teach structural design principles and construction process of temporary construction structures such as formwork. In some instances, course instruction emphasizes theory and abstract concepts that sometimes confuse students rather than clarify structural principles and/or their applications. The main objectives of this paper are to develop a course outline and course format in consultation with the industry, SPSU alumni, and based on teaching experiences of this class. There will also be an in-depth discussion about the teaching strategy, course text, course assignments and learning outcomes. The outcome of this paper can be useful to other architectural/civil engineering and construction faculties in developing and teaching this course from which students can learn state-of-the-art of temporary structures and their applications without much difficulty.
\end{abstract}

Key Words: Temporary construction structures, Construction, Architectural Engineering, Structures, Learning outcome.

\section{Introduction}

Temporary structures are the essential components required to complete a construction project. Temporary structures are also a significant cost component on many projects, and in some cases, exceeds the actual cost of the in-place construction items such as formwork. Recent studies have been found that $40 \%$ to $60 \%$ of the cost of concrete work for the building construction is for the

"Proceedings of the 2001 American Society for Engineering Education Annual Conference \& Exposition Copyright 2001, American Society for Engineering Education" 
formwork. The collapse of a temporary structure during construction involves a high risk of serious injuries, deaths and substantial property loss. A clear understanding of the design of temporary structures is a critical function not only for the designers but also for developers, contractors, suppliers of construction equipment, inspectors and all users of temporary structures. These temporary structures may pose substantial challenges for the contractors since the projects design professionals rarely mention them in the project documents. The lack of clear design, plan and specifications for these structures leaves a large number of choices open to the contractor. Since no typical plan and specifications are used in this area, contractors make serious safety and economic mistakes dealing with these works.

Constructions are becoming more complex due to the Government's rules and regulations, owner expectation and economics. This changing environment generally means more demand on efficient use of temporary structures, material selection and use of construction equipment. This demand can not be achieved without direct involvement of construction people in the preconstruction (plan and design) stage. Designers should know what temporary structures would be good for the particular structures, location and type of project. Designers should also know how they could design temporary structures to be more construction-friendly so that contractor can implement the designs without difficulty. Contractors should know what is the designer's intent of the particular design and how he can fulfill the owner/designer expectation in construction with safety and economics. Construction and architectural/civil engineering students, therefore, need a good foundation of both design and construction of temporary structures. Temporary structures require design decisions made in the context of not only cost but also interrelated issues of project schedule, safety, coordination and equipment support.

Most architecture/civil engineering and construction programs in the United States require the students to learn structural design principles. Often the students do not realize the importance of the practical applications of the structural concepts covered in these courses. In many cases, course instruction emphasizes theory and abstract concept. Many students do not understand math-oriented coursework, probably due to their marginal background in analytical skills. Even some students understand the structural courses but they can not visualize the necessity of these classes in their career, and therefore feel it is 'irrelevant'. These same students fail to realize how the structural course can be useful in constructability analysis and value engineering of the project. In some cases, they can even design and construct some small temporary structures on their own without hiring design professionals and specialty subcontractors. Whenever the student feels the problem is difficult or time consuming, he assumes that it will not be his responsibility, but would hire a consultant or a subcontractor to solve that problem. The benefit of temporary construction structures coursework is that students can apply structural principles to actual construction in the project site.

Temporary structures provide a significant element of difference from the standard structures principles course as taught to architecture/civil engineering or construction majors. In temporary structure courses, certain loads such as equipment loads are treated as dynamic components instead of as dead load. Other loads such as fresh concrete on concrete formwork systems may vary significantly depending on the placement rate, type of concrete and temperature. Students who are involved with construction should understand these differences to prevent accidents or structural failure. 
The main objective of this paper is to highlight the key elements of this course, develop a course outline, provides some ideas of course assignment and summary of course outcome.

\section{Existing Course}

The Construction Department of Southern Polytechnic State University (SPSU) has two concentrations- one is general construction and another is development. The existing course is listed as CNST 3260- Applied Structure II at SPSU for the general construction concentration. The enrollment is limited to senior or junior construction students. This course is open to all interested students of Civil Engineering and Architecture. In the past, there was no prerequisite for this course. But recently, CET 2200 was listed as a prerequisite to ensure that students have a fundamental understanding of statics and strength of materials concepts. In addition, it is expected that the students have been exposed to the basics of techniques and methods and quantity take-off of construction.

\section{Course Objectives}

The objectives of this course are to provide the capability and understanding of design and construction of a variety of temporary structures such as formwork, shoring/reshoring, underpining, dewatering, excavation and others. The student will be capable of dealing with temporary construction issues including state-of-the art developments, safety, and relevant legal and regulatory issues. The student will be able to design and analyze these structures in terms of dynamic and static loads, other technical issues, managerial issues and cost/schedule considerations. In addition, the student will understand the roles of subcontractors, suppliers, design professionals, owners, and government agencies in this area. The student will be able to present temporary structures concepts clearly and professionally from both the quantitative and qualitative standpoints.

\section{Course Format}

The course is designed with a combination of lectures and discussions. The course is offered on a 3 -credit hour basis in both fall and spring semesters. Class generally meets twice a week for a total four-hour duration. Since the SPSU construction program emphasized more on building construction rather than heavy civil construction, about $40 \%$ to $50 \%$ of semester time is spent on design, estimates, evaluation, and selection of formwork, and planning for shoring and reshoring. Due to the wide variety of temporary structures, guest speakers from the industry are utilized to provide additional industry perspectives and "real-life" components for this course. Some of the guest speakers in the past have been formwork design engineers and project managers, scaffolding contractors, and dewatering contractors. In addition, several field trips are arranged each semester to provide practical insights into the temporary structure construction, and how these benefit the total construction. Project manger/superintendent/design engineer of the site discusses the problems and limitations of the project regarding temporary structures and how they solve those problems with safety, economy and within schedule.

Class discussions may include the pros and cons of various solutions such as one-story shoring and one-story reshoring vs. one-story shoring and two-story reshoring for a four-story building, 
slurry trench method vs. open sumps for dewatering, bracket pile underpining vs. slant-augured pile underpinning and others. Students realize that decision in temporary structures impact techniques for work, project schedule, and resource allocation. Most of the students of the SPSU construction program are working full-time and part-time in the industry, and gain valuable insights for temporary structure construction. Some of them even work with the temporary structure subcontractors. These students also help to extend the class discussions and render them more valuables to the whole class.

\section{Course Assignments}

The workload for the course is comprised of a number of homework assignments, class work, class quizzes, literature reviews and text readings covering the essentials and varied aspects of this subject area. They need to design the formwork components (beam, column, wall, and slab) by using the structural formulas and using Tables developed by the American Concrete Institute (ACI). Besides the quantitative homework assignments, students were individually given readings (catastrophic failures) on temporary structure construction and required to provide a combination of written and oral reports in these areas. Since course enrollments are relatively small (about 15-20), homework assignment are given on both an individual and a group basis. The qualitative portion of the assignment explains why a particular solution was chosen such as OSHA requirements or site limitations beyond quantitative factors. One group's final project is given every semester on formwork construction. After passage of three/four weeks of the semester, each team is given a four-story building plan, drawings and specifications to design, estimates and schedule of formworks, which they are required to complete for the total building project. Planning of the shoring/reshoring, types and use of the equipment, traffic control and others also need to be discussed in the final report. The written report in part requires the production of shop drawings by the student teams because like other drawings, shop drawings do not exist in the contract documents. This is a kind of extensive report to be submitted at the end of the semester and presented in the class. This final project gives students both a "real-world" type experience plus additional practice in verbal and written communications. The emphasis to the student teams is on providing an well-organized and professional document as a temporary structure subcontractor that could be submitted to an owner or the general contractor for their review. In some semesters, several dewatering projects are given as a final project for the nonrepetition of the same projects. Two, sometimes three exams are given during the semester depending on the class progress and student performances.

An example of a more-involved course assignment might be the selection of a concrete formwork system. The student would complete their calculations and analysis to make a decision based upon:

- Preliminary assumptions such as type of cement, concrete slump and vibration

- Design details of the completed structure

- Site and climatic conditions

- Type of concrete surface finish required (architectural vs. structural concrete)

- Construction sequence and schedule allotment

- Equipment type, capacity, availability and costs

- Requirements for safety features

"Proceedings of the 2001 American Society for Engineering Education Annual Conference \& Exposition Copyright 2001, American Society for Engineering Education" 
- Support for associated temporary structures in addition to formwork as scaffolding

- Methods of concrete placement

- Form removal and form releasing agents

- Effect on other trades such as hoisting or rebar sub contractor

As can be seen, effective course assignments expose the students to many realities in this area. Students should learn that temporary structures must be designed and selected to enhance the efficiency of the construction process. In many cases such as formwork, temporary structures are in the critical path for the project's completion. Thus the best system choice may be a more expensive formwork system requiring higher crane capacity or more use of formwork to reduce the overall building completion time. This system selection means overhead savings for both the general contractor and subcontractors. In addition, the owners save on capital interest costs and improve income from earlier occupancy. Students often criticize structural design components for emphasizing design and de-emphasizing construction issues. Effective temporary structures assignments should provide an integration of both design and construction issues.

\section{Course Text and References}

There are a great variety of books for the traditional construction courses such as construction management, estimating and scheduling. But only a few choices exist for this course. At the beginning of teaching this course Handbook of Temporary Structures in Construction by Ratay was chosen as a text, considering comprehensive coverage of the subject area. But this book was not well received by the construction students, mainly due to the concentration of the design aspects rather than both design and construction aspects. Although the book provides comprehensive coverage of the temporary structures, but seem written for professional engineers. Students had difficulty to understand some of the critical aspects of the temporary structures from this book. Another weakness of the book was inadequate coverage of formwork. Under this scenario, the author selected the book Formwork for Concrete by Hurd as a text. This book covers the selection, design, materials and costs of formwork, including shoring and reshoring. Handbook of Temporary Structures was chosen as a supplementary text, and keeping several copies in the library as a reserved books so that students can use them as needed. The major drawback of both the books is the lack of proper homework applications, which are suitable for construction students. Thus the assigned homework problems have had to be developed by the instructor. In addition, Engineering News Record (ENR) and manufacturer's literatures are used in this course. ENR provides a timely and continual source of examples of innovative applications of temporary structures, and highlights the failure of temporary construction structures. Some manufacturers also provide videotapes of these applications, which are used to supplement course literatures. Many subcontractors also share information such as drawings and various calculations of temporary structures provided that sensitive information is eliminated from this course.

\section{Student Reactions}

The reaction of construction students to this course and others (structures, soils, concrete design) is simply due to the lack of interest. Since it is in their mind that they want to be construction managers rather than designers, they don't feel the need to understand temporary structures. 
These students fail to realize the correlation of a fundamental understanding of construction science principles to execution of the construction project. Sometimes, they feel that temporary structures are difficult for them to understand. To adequately perform construction in the field and in the office, s/he must be able to relate to the participants in the process including design professionals and specialized subcontractors. Temporary construction structures can show the construction students relevant aspects and applications of construction sciences. The student who has better analytical background appreciates the necessity of the coursework.

The cost of one temporary structure choice versus an alternative, i.e. constructability and value engineering is a very important aspect of this course. How one selection affects the total construction in respect of cost, schedule and safety is generally well received by the students. The course guest speaker's presentations provide valuable lessons to the students as to why they will win or lose the contract on the basis of the temporary structure decisions. The students learn from this course that temporary structure costs are not fixed costs but a variable cost, and they can control these variable costs as an efficient construction manager.

\section{Student Learning Outcome}

At the end of each semester, a course outcome evaluation and recommendation form is given to verify what students learn from this course; how comfortably and efficiently they can use temporary structures, what they may expect from this class and what are the strengths of this class (Appendix B). They were also asked to give their suggestions on how the class may be made more useful to the students for the next semester. In the last two semesters, this evaluation form was collected. The students' overall response was very positive about the class. They felt that this course improved their communication and problem solving skills, the evaluation skills of different alternatives, and the planning, design and construction skills. They understood how the temporary structures work. They answered even affirmatively when some specific questions were asked about formwork, shoring/reshoring, excavation and scaffolding. They mentioned that they are not very convinced about the text. When questions were asked about the strengths of this class, invariably they mentioned the design aspects of formwork, instructor knowledge, case studies, final projects, and field trips. The students also mentioned that more field trips, guest speaker's presentations and case studies would be helpful for the better learning outcome of this course in subsequent semesters.

\section{Conclusions}

Temporary construction structures play a significant role in the overall construction project success. Therefore, it is important to include this course as one of the core courses for the construction and architectural/civil engineering programs. Reviews of numerous construction failures and OSHA fatalities/disabling injuries justify the requirements of knowledge of temporary structures for the construction and engineering students. Available course instruction materials, while limited in comparison to other standard construction courses, are marginally adequate to provide sound education. The instructor needs to exert more effort to supplement the inadequacy of reading materials, course assignments, and case studies, and to invite guest's speakers. The instructor also needs to change the students' mindset and to make the course more interesting so that students may feel temporary structures are not very difficult to understand and these materials are essentials for the successful completion of the project.

"Proceedings of the 2001 American Society for Engineering Education Annual Conference \& Exposition Copyright 2001, American Society for Engineering Education" 


\section{Bibliography}

1. Field, J. and Carper, K.L. (1996). Construction Failure (2nd ed.), New York, John Wiley \& Sons.

2. Hurd, M.K. (1998). Formwork for concrete Sp-6. Detroit: American Concrete Institute.

3. Peurifoy, R. L. (1976). Formwork for Concrete Structures (2nd ed.), New York, McGraw-Hill.

4. Ratay, R.T. (1996). Handbook of temporray construction structures in construction (2 ${ }^{\text {nd }}$ ed.), New York, McGrawHill.

\section{GOURANGa C. BANIK, Ph.D., P.E.}

Gouranga C. Banik is an Assistant Professor in the Construction Department of Southern Polytechnic State University at Marietta, GA. Dr. Banik completed his Ph.D. in Civil Engineering from Iowa State University. He has eleven years working experience in both private and public sector as an engineer/construction manager. He is a registered professional engineer. Dr. Banik has eight refereed publications in civil/environmental engineering and construction management journals. He presented some of his research in several well-known and peer reviewed conferences like ASEE, ASCE, ASC, WEFTEC and CIB and published articles in those conference proceedings. He presented his research all over the world including the United States, Canada, Greece, and Philippines. 


\section{Appendix A}

\section{Topical Outline for Temporary Structures}

Lesson 1 Introduction, Codes, Standards and Regulations

Lesson 2 Technical and Business Practices (Design, specification, shop drawings, inspection)

Lesson 3 Formwork Materials -Recent Developments

Lesson 4 Loads \& Pressures

Lesson 5 Loads \& Pressures

Lesson 6 Form Design

Lesson 7 Field Trip*

Lesson 8 Form Design

Lesson 9 Form Design

Lesson 10 Form Design

Lesson 11 Formwork Cost/Economics/Planning

Lesson 12 Building and Erection of Formwork

Lesson 13 Test-1

Lesson 14 Shoring/Reshoring/Falsework

Lesson 15 Shoring/Reshoring/Falsework

Lesson 16 Construction Dewatering

Lesson 17 Construction Dewatering

Lesson 18 Underpinning

Lesson 19 Underpinning

Lesson 20 Scaffolding

Lesson 21 Field Trip*

Lesson 22 Test-2

Lesson 23 Earth-Retaining Structures

Lesson 24 Excavation

Lesson 25 Soil Compaction and stabilization

Lesson 26 Access Roads and Hauling, Roadway Decking

Lesson 27 Temporary Structures Equipment

Lesson 28 Underground Tunneling/Supports

Lesson 29 Protection of Site, Adjacent Areas and Utilities

Lesson 30 Legal Issues (Contractual parties, Unexpected conditions)

Lesson 31 Review/Test-3

* subject to change 


\section{Appendix B \\ Construction Department, SPSU \\ Course Outcome Evaluation and Recommendation Form}

Course Semester/Year

Mark an "X" for A = Strongly agree, $\mathrm{B}=$ Agree, $\mathrm{C}=$ No comment, $\mathrm{D}=$ Disagree, $\mathrm{E}=$ Strongly disagree.

1. This course improved my ability in problem solving skill.

A B $\mathrm{C}$ D E

2. This course improved my ability to communicate my views clearly in temporary structures.
A B $\mathrm{C}$ $\mathrm{D}$ E

3. This course helped me to develop an understanding of the ways in which temporary structures work. A B $\mathrm{C}$ $\mathrm{D}$

4. This course enhanced my understanding of the scientific disciplines and technology relevant to construction.
A B $\mathrm{C}$ $\mathrm{D}$ $\mathrm{E}$

5. I can better determine what kind of formwork I should use for my project.
A B $\mathrm{C}$ $\mathrm{D}$ E

6. If the project is of small size, I can evaluate temporary structures including formworks.
A B $\mathrm{C}$ $\mathrm{D}$ $\mathrm{E}$

7. I can evaluate soil-related minor problems and their suggestion in construction.
A B $\mathrm{C}$ $\mathrm{D}$ $\mathrm{E}$

8. I can sequence/plan shoring and reshoring during construction.
A B $\mathrm{C}$ $\mathrm{D}$ E

9. I have some ideas related to compaction and stabilization of soil. $\mathrm{A} \longrightarrow \mathrm{B} \longrightarrow \mathrm{C} \_\mathrm{D}$

10. I can suggest and use protective systems for excavation work.
A B $\mathrm{C}$ $\mathrm{D}$ E

11. I can evaluate the dewatering systems.
A B $\mathrm{C}$ $\mathrm{D}$ $\mathrm{E}$

12. I can choose the right kind of scaffolding for a building project.
A B $\mathrm{C}$
$\mathrm{D}$ $\mathrm{E}$

11. I benefited from the Text and Course Materials.
A $\mathrm{C}$ $\mathrm{D}$ $\mathrm{E}$

12. The instructor is knowledgeable about the course materials.
A $\mathrm{B}$ $\mathrm{C}$ $\mathrm{D}$ $\mathrm{E}$

13. List the strengths of this class.
i)
iii)
Ii)
iv)

14. In what way(s) do you think this course will be more useful to you in the future?

"Proceedings of the 2001 American Society for Engineering Education Annual Conference \& Exposition Copyright 2001, American Society for Engineering Education" 